\title{
Lypsylehmien muuntokelpoisen energian saannin mallinnus rehuhyötysuhdeominaisuuksien kehittämistä varten
}

Terhi Mehtiö, Enyew Negussie, Päivi Mäntysaari, Esa Mäntysaari, Martin Lidauer

Luke, Vihreä teknologia, 31600 Jokioinen, etunimi.sukunimi@luke.fi

\section{TIIVISTELMÄ}

Maidontuotanto, ylläpito ja kasvu ovat tärkeimmät tekijät, joihin lypsylehmät käyttävät energiaa ensimmäisen lypsykauden aikana. Aikaisemmissa tutkimuksissa on osoitettu, että eläinten välillä on perinnöllisiä eroja siinä miten ne jakavat energian saantia näihin eri tekijöihin - osa lehmistä käyttää enemmän energiaa maidon tuotantoon ja osa taas enemmän painon lisäämiseen tai ylläpitoon. Geneettistä vaihtelua eri rehuhyötysuhdeominaisuuksissa on tutkittu paljon. Eniten tutkittuja ominaisuuksia ovat kuiva-aineen syönti, jäännösrehun- tai energiankulutus ja erilaiset suhdeominaisuudet, jotka yleensä määritetään panosten suhteena tuotokseen. Kaikissa näissä ominaisuuksissa on kuitenkin omat ongelmansa, eivätkä ne kerro mihin eläin todella käyttää energiaansa. Tässä tutkimuksessa pyrimme jakamaan muuntokelpoisen energian saannin perinnöllisen vaihtelun sen komponentteihin eli energiakorjattuun maitoon, metaboliseen painoon (ylläpito) ja painonmuutokseen. Tutkimusaineistossa on 473 pohjoismaisen punaisen rodun ensikkoa, jotka ovat olleet mukana vuosina 1998-2014 Luken Rehtijärven ja Minkiön tutkimusnavetoiden ruokintakokeissa. Näiltä eläimiltä on mitattu syönti, paino ja maitomäärä ja tässä tutkimuksessa aineistosta käytettiin havaintoja lypsykauden viikolta 2 viikolle 40 asti. Kokonaisuudessaan analyyseissä hyödynnettiin 12802 havaintoa, jotka olivat päivittäisten havaintojen viikkokeskiarvoja. Ensimmäinen malli oli toistuvuuseläinmalli, jossa vastemuuttujana käytettiin energianmuuntoyhtälön residuaalia (residual energy intake, REI). Toinen malli oli niin sanottu korjattu energian saanti, joka on myös toistuvuuseläinmalli, mutta vastemuuttujana käytettiin muuntokelpoisen energia saantia (metabolisable energy intake, MEI) ja regressioyhtälö sisälsi energiakorjatun maidon, painon sekä painon muutoksen. Kolmas malli oli muuten edellisen kaltainen, mutta lisäksi geneettinen ja pysyvän ympäristötekijän varianssi jaettiin eläintekijälle yleensä ja energiakorjatulle maidolle. Kaikki näillä malleilla saadut periytymisasteet olivat kohtalaisia - ensimmäisellä 0,26 , toisella 0,32 ja kolmannella 0,24. Varianssikomponenttien estimointi on vaikeutunut, kun malliin lisätään painon tai painonmuutoksen komponentit, joten muuntokelpoisen energian saannin mallinnus vaatii vielä parantelua.

Asiasanat: lypsylehmä, muuntokelpoinen energia, periytymisaste 


\section{Johdanto}

Lypsylehmät käyttävät ensimmäisen tuotoskauden aikana energiaansa kolmeen eri tekijään: maidontuotantoon, ylläpitoon ja kasvuun. Lypsykauden aikana lehmät käyvät läpi suuria muutoksia muun muassa maidon koostumuksessa ja määrässä, painossa ja kuntoluokassa sekä energian tarpeessa tiineyttä varten. Lehmät käyttävät eniten energiaa maidontuotantoon lypsykauden alussa (88\% energiansaannista) ja vähiten lypsykauden lopussa (50 \% energiansaannista) (Prendiville et al., 2011). Perinteisesti metaboliakammioita on käytetty mittaamaan tehokkuutta, jolla lehmä muuntaa muuntokelpoisen energian eri tekijöihin. Selkeitä viitteitä siitä, onko näissä tehokkuuksissa perinnöllisiä eroja eläinten välillä, ei ole vielä löytynyt.

Tähän mennessä perinnöllisissä tutkimuksissa on keskitytty erilaisiin rehuhyötysuhdetta kuvaaviin ominaisuuksiin, kuten kuiva-aineen syönti, jäännösrehun- tai energiankulutus ja erilaiset suhdeominaisuudet, jotka yleensä määritetään panosten suhteena tuotokseen. Periytymisasteet kuivaaineen syönnin osalta ovat vaihdelleet eri tutkimuksissa välillä 0,27 - 0,63 (Berry et al., 2014; Liinamo et al., 2015; Spurlock et al., 2012). Jäännösrehun- tai energiankulutuksen (residual feed intake, RFI ja residual energy intake, REI) laskemiseen on eri tapoja, joten periytymisasteet vaihtelevat huomattavasti eri tutkimusten välillä $(0,01-0,32)$ (Liinamo et al., 2015; Tempelman et al., 2015; Pryce et al., 2014). Nämä RFI- ja REI-ominaisuudet ovat monestakin syystä ongelmallisia, jos niitä halutaan käyttää jalostustavoitteina. Malleihin on hankalaa sisällyttää kaikki tarvittavat komponentit, jolloin havainnot ovat epätarkkoja. Lisäksi ominaisuuden ei voida olettaa olevan biologisesti riippumaton sen komponenttiominaisuuksista (Pryce et al., 2014). Viimeisimmissä tutkimuksissa on myös osoitettu, että REI:n ja energiataseen väliltä löytyi positiivinen yhteys, eli tehokkaammat eläimet ovat odotettavasti suuremmassa negatiivisessa energiataseessa, millä on taas yhteys esimerkiksi huonontuneeseen hedelmällisyyteen (Hurley et al., 2015). Näistä syistä RFI:lle ja REI:lle on viime aikoina yritetty etsiä vaihtoehtoisia lähestymistapoja. Kuiva-aineen syöntiä on esimerkiksi mallinnettu yhdessä maidon energian, metabolisen painon ja painonmuutoksen kanssa (Lu et al., 2015) ja uudessa "säästetty rehu" -ominaisuudessa RFI:hin on yhdistetty ylläpitotarpeet (Pryce et al., 2015). Silti ongelmana näissä ominaisuuksissa on se, että ne eivät heijasta sitä miten lehmät jakavat energian ylläpitoon, maidontuotantoon tai kasvuun. Tästä syystä on mielekkäämpää mallintaa suoraan muuntokelpoisen energian saanti (metabolisable energy intake, MEI) RFI:n tai REI:n sijaan. Kun mallissa jaetaan geneettinen tekijä eri energiatarpeille, on myös mahdollista arvioida näiden osittaisten tehokkuuksien jalostusarvot olettaen, että niissä on perinnöllisiä eroja eläinten välillä.

Tässä tutkimuksessa pyrimme arvioimaan muuntokelpoisen energian ja sen komponenttien tehokkuuden perinnöllistä vaihtelua. Tätä varten vertasimme erilaisia toistuvuusmalleja REI:lle ja MEI:lle, ja jaoimme eläinten välisen perinnöllisen ja ei-perinnöllisen vaihtelun MEI:n yksittäisiin komponentteihin eli energiakorjatulle maitotuotokselle (EKM), metaboliselle painolle (elopaino ${ }^{0.75}$ ) sekä painonmuutokselle.

\section{Aineisto ja menetelmät}

Tutkimuksessa käytetty aineisto on kerätty useiden eri ruokintakokeiden aikana Luonnonvarakeskuksen tutkimusnavetoissa Rehtijärvellä ja Minkiössä vuosina 1998-2014. Tiivistelmän kirjoittamisen jälkeen tutkimusaineisto on päivitetty lisäämällä siihen 22 lehmää sekä niiden havainnot. Kaiken kaikkiaan aineistossa oli siis mukana 495 punaisen rodun ensikkoa ja yhteensä 12350 viikoittaista havaintoa lypsykauden toiselta viikolta viikolle 40. Ensimmäisen viikon havainnot poistettiin, koska tutkittavissa ominaisuuksissa oli lypsykauden alussa paljon vaihtelua, mikä vaikeutti perinnöllisiä analyysejä. Painonnousut lypsykauden toisella viikolla ja painonpudotukset viikon 15 jälkeen asetettiin nolliksi. Näiden oletettiin olevan potentiaalisia virhemittauksia, jotka aiheutuivat satunnaisista punnitustuloksista.

Tutkitut ominaisuudet olivat muuntokelpoisen energian saanti (metabolisable energy intake, MEI, MJ/pv), energiakorjattu maitotuotos (EKM, kg/pv), metabolinen elopaino ( $\mathbf{m B W}=$ elopaino ${ }^{0.75}$, $\mathrm{kg})$, painonpudotus $(\boldsymbol{\Delta} \mathbf{B W}, \mathrm{kg} / \mathrm{pv})$, painonnousu $\left(\boldsymbol{\Delta} \mathbf{B W} \mathbf{W}_{+}, \mathrm{kg} / \mathrm{pv}\right)$ sekä jäännösenergiankulutus (residual energy intake, REI, ME MJ/pv). Lehmän paino ja painonmuutos ennustettiin päivittäisistä 
punnituksista (Mäntysaari \& Mäntysaari, 2015). Jäännösenergiankulutus laskettiin sovittamalla MEI:lle regressiomalli, joka sisälsi EKM:n, mBW:n ja painonmuutoksen. Mallin residuaalien viikoittaisia lehmäkohtaisia keskiarvoja käytettiin eläinten REI -havaintoina. Muuntokelpoisen energian saanti perustui kuiva-aineen syöntiin ja kuiva-aineen energia-arvoihin. Rehujen energia-arvot laskettiin rehutaulukoiden mukaisesti (Luke, 2015). Päivittäinen MEI korjattiin kokonaiskuiva-aineen syönnillä ja ME:n ja proteiinin pitoisuudella Luken korjausyhtälön mukaisesti. Rehunäytteiden keräys ja analyysit on kuvattu tarkemmin aikaisemmissa tutkimuksissa (Mäntysaari et al., 2003, 2004, 2005).

Tutkimusaineistossa ME saanti kasvoi viikoilla 2-15 poikimisen jälkeen $(183,28$ - 214,92 $\mathrm{MJ} / \mathrm{pv}$ ) ja pysyi sen jälkeen samalla tasolla, kunnes taas putosi viimeisessä lypsykauden vaiheessa. Maidontuotanto kasvoi viikoilta $2-15$ poikimisen jälkeen $(27,99-29,53 \mathrm{~kg} / \mathrm{pv})$ ja alkoi sen jälkeen vähentyä. Metabolinen elopaino kohosi koko lypsykauden ajan $(116,51-125,71 \mathrm{~kg})$. Painonnousu alkoi viikolta 3 poikimisen jälkeen ja kasvoi koko lypsykauden ajan $(0,07-0,51 \mathrm{~kg} / \mathrm{pv})$. Painonlaskun havainnot asetettiin nolliksi viikon 15 jälkeen ja näin ollen painonlaskun arvoja on vain kolmesta ensimmäisestä lypsykauden vaiheesta. Painonlasku oli suurinta alkulypsykaudesta $(-0,45 \mathrm{~kg} / \mathrm{pv})$ ja väheni sen jälkeen toisessa ja kolmannessa lypsykauden vaiheessa.

Perinnöllisissä analyyseissä käytettiin eläinten sukutietoja neljän sukupolven päähän, jolloin koko sukulaisuusaineisto käsitti 2409 eläintä.

\section{Ominaisuudet}

Vaihtoehtona REI:lle tutkimme uusia ominaisuuksia muuntokelpoisen energian käyttökyky (metabolisable energy efficiency, MEE) ja ositettu muuntokelpoisen energian käyttökyky (partial metabolisable energy efficiency, pMEE). Muuntokelpoisen energian käyttökyvyssä energian käyttö ylläpitoon, maidontuotantoon ja painonmuutokseen on sovitettu suoraan malliin kiinteinä regressiotekijöinä. Ositetun muuntokelpoisen energian käyttökyvyn mallissa myös perinnöllinen ja eiperinnöllinen vaihtelu on jaettu näille regressiotekijöille, jolloin jalostusarvot on mahdollista arvioida osittaisille tehokkuuksille erikseen.

\section{Tilastolliset mallit}

Ensimmäiseksi sovitimme REI:lle kontrolli- ja referenssianalyysinä toistuvuuseläinmallia, jotta voisimme myöhemmin vertailla tällä mallilla estimoituja varianssikomponentteja muiden mallien tuloksiin:

Mallissa vastemuuttujana on $\mathrm{REI}_{\mathrm{ij}}$ eli jäännösenergiansaanti (ME MJ/pv), $v k k$ on kiinteä mittausvuosikuukausitekijä $i, a_{j}$ on eläimen $j$ satunnainen additiivinen perinnöllinen eläinvaikutus, $p e_{j}$ on satunnainen ei-perinnöllinen eläinvaikutus $j$ ja $\epsilon_{\epsilon \epsilon}$ on satunnainen virhetermi.

Energiankäyttö mallinnettiin ensin pienimmän neliösumman mallilla, jotta nähtiin kuinka kiinteät regressiotekijät vaihtelivat lypsykauden aikana:

Mallissa $M E I_{i s}$ on muuntokelpoisen energian saanti (MJ/pv), $v k k$ on kiinteä mittausvuosikuukausitekijä $i, b_{c}$ on kiinteä regressiotekijä $\mathrm{c}=1,2,3,4$ (ylläpidon ja maidontuotannon sekä elopainon nousun ja laskun regressiokertoimet), $m B W_{i s}$ on metabolinen paino $(\mathrm{kg}), E K M_{i s}$ on energiakorjattu maitotuotos (kg/pv), $\Delta B W_{+i s}$ on painonnousu $(\mathrm{kg} / \mathrm{pv}), \Delta B W_{\text {-is }}$ on painonlasku $(\mathrm{kg} / \mathrm{pv})$, laktlk $_{s}$ on lypsykauden luokka (8 eri luokkaa: 2-5, 6-10, 11-15, 16-20, 21-25, 26-30, 31-35, 36-40 viikkoa) ja $\epsilon_{\epsilon \epsilon}$ on satunnainen virhetermi.

Toisin kuin REI:n toistuvuusmallissa, MEE analyysissä mallinnettiin MEI-havainnot ja energian käyttö samanaikaisesti:

Tässä mallissa kiinteät tekijät olivat samat kuin pienimmän neliösumman mallissakin. Lisäksi mallissa oli satunnainen additiivinen perinnöllinen vaikutus $a_{l}$ eläimelle $l$, satunnainen ei-perinnöllinen vaikutus $\mathrm{pe}_{l}$ eläimelle $l$ sekä satunnainen virhetermi $\epsilon_{\epsilon \epsilon \epsilon}$. 
Ositetut tehokkuudet mallinnettiin satunnaisregressiomallilla, jossa jaettiin perinnöllinen ja eiperinnöllinen vaikutus MEI:n osamuuttujille EKM:lle, mBW:lle, painonnousulle ja -laskulle sekä eläimen yleistasolle:

Mallissa jälleen kiinteät tekijät olivat samat kuin kahdessa edellisessä mallissa, mutta $a_{c l}$ on satunnainen additiivinen perinnöllinen regressiokerroin $c=0, . ., 4$ (eläimen yleistason, ylläpidon, maidontuotannon sekä elopainon nousun ja laskun regressiokertoimet) eläimelle $l, p e_{c l}$ on satunnainen ei-perinnöllinen regressiokerroin $\mathrm{c}=0, . ., 4$ eläimelle $l \quad$ ja $\epsilon_{i s l}$ on satunnainen virhetermi. Kovarianssimatriisit ovat $\operatorname{var}(\mathbf{a})=\boldsymbol{G}_{5 \times 5} \otimes \boldsymbol{A}$ ja $\operatorname{var}(\mathbf{p e})=\boldsymbol{P}_{5 \times 5} \otimes \boldsymbol{I}$ ja $\mathbf{A}$ on eläinten additiivinen sukulaisuusmatriisi.

\section{Perinnöllisten tunnuslukujen estimointi}

Varianssikomponentit laskettiin DMU-ohjelmalla (Madsen ja Jensen, 2013) REMLmenetelmällä käyttäen kaikille toistuvuusmalleille Average Information -maksimointitapaa (AIREML) ja satunnaisregressiomallille käyttäen Expectation Maximisation -algoritmia (EM-REML).

Toistuvuusmallin tuloksista periytymisasteet REI:lle ja MEE:lle laskettiin perinnöllisen varianssin suhteena fenotyyppiseen varianssiin. Satunnaisregressiomallilla periytymisasteet laskettiin jokaiselle lypsykauden vaiheelle fiktiiviselle lehmälle, eli sovellettavat kovariaabelit tietyssä lypsykauden vaiheessa $s$ olivat mBW:n, EKM:n, painonnousun ja painonlaskun keskiarvoja aineistossa. Näin ollen kovariaabelivektori lypsykauden luokassa $s$ oli

jossa $\bar{m}$ on metabolisen elopainon keskiarvo, - on energiakorjatun maitotuotoksen keskiarvo, $\quad$ on painonnousun keskiarvo and - on painonlaskun keskiarvo jokaisessa lypsykauden luokassa.

Tämän jälkeen additiivinen perinnöllinen ja ei-perinnöllinen varianssi laskettiin seuraavilla tavoilla:

ja

joissa $E$ oli satunnaisen additiivisen perinnöllisen vaikutuksen ja $E$ ei-perinnöllisen vaikutuksen kovarianssimatriisi. Näin ollen satunnaisregressiomallilla laskettiin kahdeksan periytymisastetta - yksi jokaiselle lypsykauden vaiheelle.

\section{Tulokset}

Energian käyttö maidontuotantoon tästä aineistosta laskettuna oli 2,89 MJ x EKM (kg/pv) koko lypsykauden aikana ja ratkaisut kasvoivat 1,79 MJ:sta 3,76 MJ:een lypsykauden edetessä. Ylläpitoenergian käyttö oli $0,77 \mathrm{MJ} / \mathrm{BW}^{0.75}(\mathrm{~kg})$ ja se vaihteli välillä 0,60 - 1,04 MJ lypsykauden aikana. Energian käyttö painonmuutokseen oli painonlaskun osalta $20,40 \mathrm{MJ} / \mathrm{kg}$ ja painonnousun osalta $22,51 \mathrm{MJ} / \mathrm{kg}$. Nämä ratkaisut vaihtelivat melko paljon lypsykauden aikana (painonlaskun osalta $10,07-19,89 \mathrm{MJ} / \mathrm{kg}$ ja painonnousun osalta $9,50-23,68 \mathrm{MJ} / \mathrm{kg}$ ).

\section{Perinnölliset tunnusluvut}

Periytymisasteet energiansaannille eri malleilla olivat keskinkertaisia (Taulukko 1). Additiivinen geneettinen varianssi oli korkein REI:n toistuvuusmallilla estimoituna $(166,40)$ ja matalin pMEE:n satunnaisregressiomallilla estimoituna $(111,88)$. Residuaalivarianssi oli pienin $(186,99)$ pMEE:lla. Kun pMEE:lle arvioituja varianssikomponentteja käyttäen laskettiin periytymisasteet kaikissa eri lypsykauden vaiheissa, periytymisasteet pysyivät välillä 0,22 ja 0,23 lypsykauden alusta 
viikkoon 25 asti. Loppulypsykaudesta ei-geneettinen varianssi kasvoi, koska painonnousun eigeneettinen varianssi kasvoi ja painonnousu lisääntyi. Tästä johtuen myös periytymisaste laski loppulypsykaudesta.

Regressiotekijöiden geneettiset varianssit vaihtelivat välillä 0,008 ja 0,169 (Taulukko 2). Geneettiset kovarianssit olivat erittäin alhaisia, lähelle nolla kaikkien regressiotekijöiden välillä. Eigeneettiset varianssit vaihtelivat välillä 0,081 ja 3705,066.

Taulukko 1. Varianssien estimaatit ja periytymisaste $\left(\mathrm{h}^{2}\right)$ eri malleilla. REI on toistuvuusmalli jäännösenergiansaannille, MEE on toistuvuusmalli muuntokelpoisen energian käyttökyvylle ja pMEE on satunnaisregressiomalli ositetulle muuntokelpoisen energian käyttökyvylle lypsykauden eri vaiheissa.

\begin{tabular}{lcccc}
\hline Malli & $\sigma_{\mathrm{a}}^{2}$ & $\sigma_{\mathrm{pe}}^{2}$ & $\sigma_{\mathrm{e}}^{2}$ & $\mathrm{~h}^{2}$ \\
\hline REI & 166,40 & 167,33 & 310,22 & 0,26 \\
MEE & 125,82 & 154,35 & 254,94 & 0,24 \\
pMEE & 111,88 & 187,55 & 186,99 & 0,23 \\
Vaihe 1 & 110,43 & 192,03 & 186,99 & 0,23 \\
Vaihe 2 & 120,30 & 237,64 & 186,99 & 0,22 \\
Vaihe 3 & 120,92 & 213,13 & 186,99 & 0,23 \\
Vaihe 4 & 116,19 & 199,22 & 186,99 & 0,23 \\
Vaihe 5 & 111,88 & 221,25 & 186,99 & 0,22 \\
Vaihe 6 & 113,40 & 284,43 & 186,99 & 0,19 \\
Vaihe 7 & 114,98 & 447,16 & 186,99 & 0,15 \\
Vaihe 8 & 113,06 & 556,27 & 186,99 & 0,13 \\
\hline
\end{tabular}

Taulukko 2. Ositetun muuntokelpoisen energian käyttökyvyn (pMEE) regressiotekijöiden geneettiset $\left(\sigma^{2}{ }_{a}\right)$ ja ei-geneettiset $\left(\sigma_{\text {pe }}^{2}\right)$ varianssit.

\begin{tabular}{lll}
\hline Regressiotekijä & $\sigma^{2}{ }_{a}$ & $\sigma_{p e}^{2}$ \\
\hline Vakio & 0,010 & 0,081 \\
BW $^{0.75}$ & 0,008 & 0,192 \\
EKM & 0,169 & 2,554 \\
BWG & 0,013 & 3705,066 \\
BWL & 0,014 & 637,440
\end{tabular}

Geneettiset keskihajonnat maidontuotantoon käytettävän energian (EKM:n) regressiokertoimen osalta näyttävät, että eläinten jalostusarvojen vaihtelu näyttää suuremmalta EKM:n tuotantotason noustessa (Kuva 1). Keskiarvo on otettu pienimmän neliösumman mallin ratkaisuista. Kuvasta nähdään, että tehokkaimmat lehmät käyttävät muuntokelpoisesta energiasta maidontuotantoon tämän aineiston perusteella 2,48 MJ/EKM kg ja tehottomimmat lehmät 3,30 MJ/EKM kg. Tehokkaamman lehmän lypsäessä $25 \mathrm{~kg}$ maitoa, se kuluttaa maidontuotantoon muuntokelpoista energiaa noin $62 \mathrm{MJ}$. Tehottoman lehmän lypsäessä saman verran, se kuluttaa maidontuotantoon energiaa 20,5 MJ ME enemmän. Samalla tavalla vaihtelu kasvaa myös metabolisen elopainon osalta. Tehokkaimmat lehmät tarvitsevat muuntokelpoista energiaa tämän aineiston perusteella ylläpitoon $0,68 \mathrm{MJ} / \mathrm{kg}$ ja tehottomimmat lehmät $0,86 \mathrm{MJ} / \mathrm{kg}$. Keskimääräisen metabolisen elopainon ollessa noin $120 \mathrm{~kg}$ (eli noin 590 kg:n elopaino), tehokkaammat lehmät käyttävät ylläpitoon 81,6 MJ ja tehottomammat 103,2 MJ. Painonmuutosten geneettiset keskihajonnat olivat niin pieniä, ettei eroja voitu tästä aineistossa nähdä. 
Kuva 1. Energiakorjatun maitotuotoksen geneettisen keskihajonnan kuvaaja. Keskimääräinen energian käyttö maidontuotantoon pienimmän neliösumman menetelmällä laskettuna oli 2,89 MJ/EKM kg, jolloin jalostusarvojen keskihajonnan ollessa 0,41 , tehokkaimmat lehmät käyttävät maidontuotantoon energiaa 2,48 $\mathrm{MJ} / \mathrm{EKM} \mathrm{kg}$ ja tehottomimmat lehmät 3,30 MJ/EKM kg.

EKM jalostusarvojen keskihajonta $(0,41)$

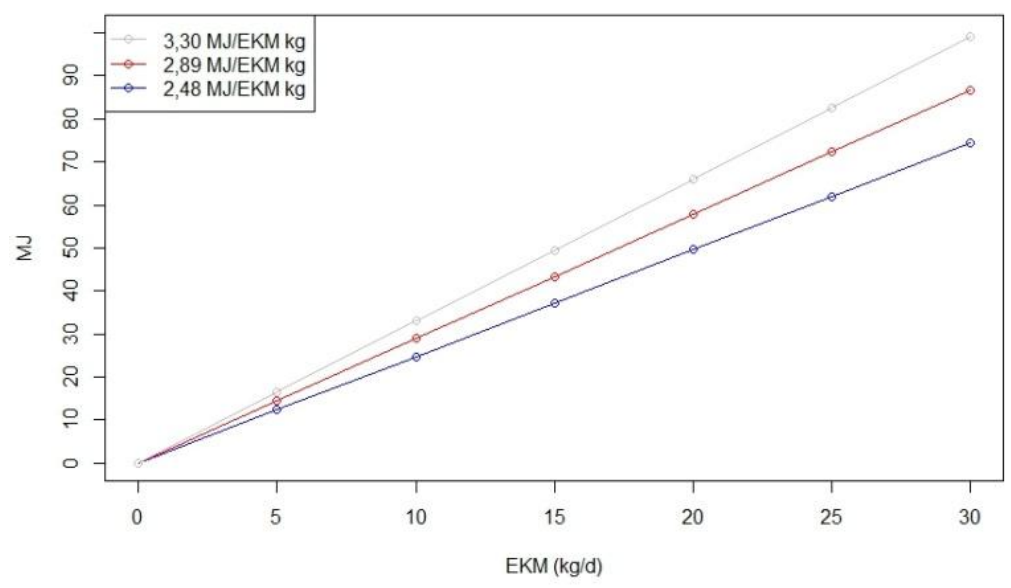

\section{Tulosten tarkastelu}

Pienimmän neliösumman menetelmällä estimoidut regressiotekijöiden ratkaisut vaihtelivat huomattavasti lypsykauden vaiheiden välillä ja lypsykauden vaiheiden huomioiminen satunnaisregressiomallissa paransi sen konvergenssia. Näin ollen oli järkevää ottaa mukaan lypsykauden vaiheen yhdysvaikutus kiinteiden regressiotekijöiden kanssa kaikissa malleissa. Tästä aineistosta lasketut energiankäyttöarvot erosivat jonkin verran Suomessa käytössä olevista rehutaulukkoarvoista. Myös muissa tutkimuksissa on huomattu vaihtelua energian käytöissä eri maissa ja tutkimusnavetoissa, ja tämän on arveltu joko tilastollisista eroavaisuuksista energian käytön arvioinnissa tai sitten todellisista eroista energian käytössä eläinten ja karjojen välillä (Tempelman et al., 2015).

Tässä tutkimuksessa löydetyt keskimääräiset periytymisasteen estimaatit olivat hieman korkeampia kuin aikaisemmissa tutkimuksissa, mutta kuitenkin samansuuntaisia (Liinamo et al., 2015; Tempelman et al., 2015; Pryce et al., 2014). Ehdottamamme toistuvuusmalli MEE:lle toimi hyvin ja jopa paremmin kuin REI:n toistuvuusmalli. Residuaalivarianssi oli pienempi MEE:1lä kuin REI:1lä ja periytymisaste MEE:llä oli vain hieman pienempi.

Useissa tutkimuksissa on huomattu RFI:n ja REI:n periytymisasteiden vaihtelevan huomattavasti lypsykauden aikana (Liinamo et al., 2015; Tempelman et al., 2015). MEE:n osalta tässä tutkimuksessa huomioimme lypsykauden vaiheen yhdysvaikutukset regressiotekijöiden kanssa mallissa, jolloin saimme vain yhden periytymisasteen estimaatin. Satunnaisregressiomallilla pMEE:lle oli mahdollista laskea periytymisaste jokaiselle lypsykauden vaiheelle erikseen ja huomasimme periytymisasteen laskevan loppulypsykautta kohti. Tämä johtui kuitenkin erittäin suuresta painonmuutoksen ei-geneettisestä varianssista ja myös fenotyyppisen painonmuutoksen kasvusta loppulypsykaudesta. Satunnaisregressiomallin konvergoitumisessa oli ongelmia. Malli oli hyvin herkkä varianssikomponenttien lähtöarvoille ja korkeat varianssikomponenttien keskivirheet osoittivat, etteivät tulokset olleet luotettavia. Yksi mahdollinen syy tähän voi olla vain ensikoista koostuva aineisto. Luken tutkimusnavetassa seosrehulla ruokituilla ensikoilla on lypsykauden aikana varsin vähän vaihtelua niin tuotantotasossa kuin kuiva-ainesyönnissäkin. Energian saannin osittaminen eri fysiologisille toiminnoille näyttää kuitenkin toimivan kohtuullisesti ja suuremmalla ja enemmän vaihtelevalla tutkimusaineistolla on mahdollista saada lisää mielenkiintoisia tuloksia. Jo tästä aineistosta geneettiset keskihajonnat osoittavat, että suurin osa perinnöllisestä vaihtelusta on maidontuotantoon ja ylläpitoon käytettävässä energiassa. 


\section{Johtopäätökset}

Uusi rehuhyötysuhdeominaisuus muuntokelpoisen energian käyttökyky (MEE) toimi tällä aineistolla hyvin ja jopa paremmin kuin aiemmin paljon käytetty REI. Energiatarpeiden huomioiminen suoraan mallissa pienensi virhevarianssia ja ominaisuus on helpompi ymmärtää kuin energianmuuntoyhtälön residuaali. Aineistomme rakenne asettaa rajoituksensa muuntokelpoisen energian saannin osittamiseen, mutta saimme kuitenkin selkeitä viitteitä siitä, että maidontuotantoon ja ylläpitoon käytettävässä energiassa on perinnöllisiä eroja eläinten välillä.

\section{Kirjallisuus}

Berry, D.P., Coffey, M.P., Pryce, J.E., de Haas, Y., Lovendahl, P., Krattenmacher, N., Crowley, J.J., Wang, Z., Spurlock, D., Weigel, K., Macdonald, K. \& Veerkamp, R.F. 2014. International genetic evaluations for feed intake in dairy cattle through the collation of data from multiple sources. J. Dairy Sci. 97: 3894-3905.

Hurley, A.M., López-Villalopos, N., McParland, S., Kennedy, E., Lewis, E., O’Donovan, M., Burke, J.L. \& Berry, D.P. 2016. Inter-relationships among alternative definitions of feed efficiency in grazing lactating dairy cows. J. Dairy Sci. 99: 1-12.

Liinamo, A.-E., Mäntysaari, P., Lidauer, M.H. \& Mäntysaari, E.A. 2015. Genetic parameters for residual energy intake and energy conversion efficiency in Nordic Red dairy cattle. Acta Agr. Scand., A-An. DOI: 10.1080/09064702.2015.1070897

Littell, R.C., Milliken, G.A., Stroup, W.W. \& Wolfinger, R.D. 1996. SAS System for Mixed Models. SAS Institute Inc, Cary, NC, USA.

Lu, Y., Vandehaar, M.J., Spurlock, D.M., Weigel, K.A., Armentano, L.E., Staples, C.R., Connor, E.E., Wang, Z., Bello, N.M. \& Tempelman, R.J. 2015. An alternative approach to modeling genetic merit of feed efficiency in dairy cattle. J. Dairy Sci. 98: 6535-6551.

Luke. 2015. Rehutaulukot ja ruokintasuositukset. Saatavilla osoitteessa: https://portal.mtt.fi/portal/page/portal/Rehutaulukot/Ruokintasuositukset/Marehtijat/ Lypsylehmien_energian_tarve (19.11.2015)

Madsen, P. \& Jensen, J. 2013. DMU A Package for Analysing Multivariate Mixed Models. Version 6, release 5.2. Center for Quantitative Genetics and Genomics Dept. of Molecular Biology and Genetics, University of Aarhus Research Centre Foulum Box 50, 8830 Tjele Denmark.

Mäntysaari, P., Huhtanen, P. \& Nousiainen, J. 2003. The effect of constant or variable forage to concentrate ratio in total mixed ration on performance of primiparous dairy cows. Livest Prod Sci. 82: 27-37.

Mäntysaari, P., Huhtanen, P., Nousiainen, J. \& Virkki, M. 2004. The effect of concentrate crude protein content and feeding strategy of total mixed ration on performance of primiparous dairy cows. Livest Prod Sci. 85: 223-233.

Mäntysaari, P., Huhtanen, P., Nousiainen, J. \& Virkki, M. 2005. The effect of protein-feeding strategy during lactation on performance of primiparous dairy cows fed total mixed ration. Livest Prod Sci. 94: 189198.

Mäntysaari, P., Liinamo, A.-E. \& Mäntysaari, E.A. 2012. Energy efficiency and its relationship with milk, body, and intake traits and energy status among primiparous Nordic Red dairy cattle. J. Dairy Sci. 95: 32003211 .

Mäntysaari, P. \& Mäntysaari, E.A. 2015. Modeling of daily body weights and body weight changes of Nordic Red Cattle cows. J. Dairy Sci. 98: 6992-7002.

Prendiville, R., Pierce, K.M., Delaby, L. \& Buckley, F. 2011. Animal performance and production efficiencies of Holstein-Friesian, Jersey and Jersey $\times$ Holstein-Friesian cows throughout lactation. Livest. Sci. 138: 25-33.

Pryce, J.E., Gonzales-Recio, O., Nieuwhof, G., Wales, W.J., Coffey, M.P., Hayes, B.J. \& Goddard, M.E. 2015. Hot topic: Definition and implementation of a breeding value for feed efficiency in dairy cows. J. Dairy Sci. 98: 7340-7350.

Pryce, J.E., Wales, W.J., de Haas, Y., Veerkamp, R.F. \& Hayes, B.J. 2014. Genomic selection for feed efficiency in dairy cattle. Animal 8: 1-10.

Spurlock, D.M., Dekkers, J.C.M., Fernando, R., Koltes, D.A. \& Wolc, A. 2012. Genetic parameters for energy balance, feed efficiency, and related traits in Holstein cattle. J. Dairy Sci. 95: 5393-5402.

Tempelman, R.J., Spurlock, D.M., Coffey, M., Veerkamp, R.F., Armentano, L.E., Weigel, K. A., de Haas, Y., Staples, C.R., Connor, E.E., Lu, Y. \& VandeHaar, M. J. 2015. Heterogeneity in genetic and nongenetic variation and energy sink relationships for residual feed intake across research stations and countries. J. Dairy Sci. 98: 2013-2026. 